\title{
HAMBATAN DALAM PENGEMBANGAN EKONOMI KREATIF DI KABUPATEN LOMBOK TENGAH (STUDI KASUS PADA PERAJIN KAIN TENUN TRADISIONAL DUSUN SADE)
}

\author{
Oleh \\ I Gusti Ayu Oka Netrawati'), I Gusti Putu Bagus Suastina ${ }^{2)}$ \& Jumawan Ali ${ }^{3)}$ \\ 1,2,3 STIE 45 MATARAM \\ Email: ${ }^{1}$ igaokanetrawati2017@ gmail.com, ${ }^{2}$ suastina1957@ggmail.com \& \\ 3joemhero@gmail.com
}

\begin{abstract}
Abstrak
Desa Sade merupakan ikon NTB di dunia pariwisata, karena keunikan budaya dan khas sebagai perajin kain tenun tradisional. Sebagai pelaku bisnis perajin banyak menghadapi masalah pada pengelolaan marketing mix yaitu 4 P (Product,Price,Place \& Promotion). Tujuan penelitian ini untuk mengetahui permasalahan dari hambatan yang dihadapi kelompok perajin Desa Sade,dalam mengembangkan bisnis kain tenun tradisional Metode analisis yang digunakan adalah diagram Fishbone , mencari akar penyebab masalah. Hasil permasalahan yang dihadapi faktor utamanya adalah manajemen kualitas dengan pendekatan manajemen pemasaran, dan faktor pendukungnya seperti kualitas bahan baku, metode pengerjaan sangat tradisional,permodalan penentuan harga dan saluran distribusi, belum efektif dan efisien, serta kurangnya promosi..Kesimpulannya hambatan dalam mengembangkan ekonomi kreatif adalah manajememen kualitas dengan pendekatan marketing mix . Saran untuk perajin, pemerintah dan mitra kerja adalah perlu melakukan inovasi bauran pemasaran. Keterbatasan penelitian ini belum diketahuinya bagaimana strategi bisnis untuk kestabilan pasar di era revolusi indusri 4.0.
\end{abstract}

\section{Kata Kunci : Kendala Bisnis, Manajemen, Kreatifitas \& Inovatif}

\section{PENDAHUALUAN}

Keunikan Kampung Sade menjadi salah satu ikon sector pariwisata NTB karena desa ini mempunyai alam perbukitan yang asri dan sifat gotong royong dan rasa memiliki, yang kuat dan eksis sampai saat ini di jaman era globalisasi. Masyarakat dalam mengambil keputusan untuk desanya adalah hasil musyawarah dan mufakat. Bentuk dari rumah tinggal sangat unik dan tradisional serta dalam pemeliharaan rumah untuk lantainya mereka pergunakan kotoran kerbau untuk mengepel. Keunikan dari masyarakatnya dapat ditinjau dari empat aspek yaitu aspek budaya, agama, sosial dan ekonomi. Dari aspek budaya yaitu masih mempertahankan kesenian tradisional dan arsitektur bangunan yang unik dengan bentuk bangunan menyerupai lumbung dan dan posisis rumah masih banyak menyerupai Bali dan Jawa seperti ada Bale kambang atau joglo. Aspek Agama mereka masih meneruskan ajaran Waktu http://ejurnal.binawakya.or.id/index.php/MBI telu,atau Wetu telu yang artinya adalah mempunyai 3 tujuan dalam berpikir, berkata dan berbuat yang baik, Selalu ditekankan pada warga kampung Sade. Bukan melaksanakan sholat 3 kali tetapi 5 kali. Inilah keunikan dari aspek rohaniahnya. Aspek Sosial mereka punya awigawig atau aturan yang harus dijaga dan dilaksanakan dengan baik, ada sangsi jika dilanggar. Berkaitan dengan pendidikan ada perbedaan antara para lelaki dan wanita. Sesuai dengan tujuan pendidikan nasional yaitu mencerdaskan bangsa untuk menuju adil dan makmur belum menjadi realita bagi para wanita.Karena ada keterbatasan bagi kaum wanita untuk mengikuti pendidikan atas, hanya cukup bisa baca tulis. Kaum wanita ini menerima kodratnya sebai hamba Tuhan bahwa menjadi ibu rumah tangga. Tetapi keunikannya bahwa mereka diberi ketrampilan untuk menenun sebagai syarat bahwa mereka sudah boleh menikah dan secara tidak langsung dapat menjadi sebuah kemampuan

Vol.14 No.4 Nopember 2019 
yang dimiliki untuk membantu ekonomi keluarga. Pendidikan dapat juga menjadi salah satu hambatan utnuk pengembangan ekonomi kreatif , karena kurangnya kemampuan manajerial dan kompetensi dalam ilmu ekonomi. Sehingga pengembangan manajemen bisnis dapat terhambat.sehingga berpengaruh terhadap aspek ekonomi seperti kegiatan manajemen pemasaran disamping kegiatan lainnya. , sehingga sulit menerapkan manajemen professional. Masih melakukan manajemen konvensional dalam usahanya. Dengan pendidikan yang tinggi diharapkan dapat meningkatkan ekonomi pembangunan secara kreatif dan inovatif. Pembatasan lingup penelitian karena beaya , tenaga dan waktu maka dilihat dari aspek ekonominya.

Pada aspek ekonomi, dari manajemen strategi mereka memiliki kekuatan pada pengelolaan pendapatan yaitu pendapatan dari sumbangan wisatawan dengan sukarela yang datang ke lokasi wisata tersebut menjadi pendapatan desa dan dalam usaha dagangnya juga mempunyai keunikan tersendiri bahwa setiap kelompok usaha tersebut terdiri dari 5-6 kepala keluarga , modal bersama Persaingan sehat dalam memberi harga barang, namun ada kelemahannya adalah belum tepat. dalam penentuan harga produksi.sehingga akan berdampak pada penetapan harga jual. Karena penentuannya secara konvensional. Produk yang dihasilkan terbatas, karena teknik pengerjaannya adalah masih dengan alat tenun bukan mesin (ATBM), yaitu sek-sek, pekerja duduk dilantai. Dilihat dari faktor kesehatan sangat riskan karena dapat meningkatkan tingkat kelelahan terutama sakit pada kaki dan pinggang, punggung. Akan tetapi ini keunikan di satu sisi tetapi di sisi lain tidak dapat berproduksi maksimal. Contoh harga kain tenun yang dihasilkan dalam jangka waktu 2 bulan hanya seharga Rp.600.000,- - Rp.. 1.000.000,- Dan selendang dikerjakan selama 2 hari hanya berlisar Rp 8.000 - 15.000,-. , bahan baku tidak terlalu sulit diperoleh, tersedia di pasaran atau dari hasil produk sendiri dari memintal kapas menjadi benang tetapi stock terbatas dan tidak ada standar kualitas benang tetapi jika tdak di jaga maka

Vol.14 No.4 Nopember 2019 bahan baku akan dapat menjadi kendala. Sedangkan benang emas dibeli dari luar. Pengerjaannya sangat memerlukan ketelitian yang tinggi agar hasilnya berkualitas. Kekuatan yang dimiliki adalah sifat kebersamaan dan gotong royong dalam berbisnis karena itu sesuai dengan aturan yang ada dan memiliki kompetensi menenun yang membuatnya lebih kuat dari para pesaing. Citra positif karena hasil tenun tradisional yang unik masih di buat secara manual Kelemahannya kurangnya kreatifitas dalam mendesain motif khas Sasak sulitnya untuk mencari bahan alat tenun yang langka, ketrampilan pemasaran yang tidak sesuai dengan tuntutan pasar, kemampuan manajerial yang rendah, dan perolehan keuntungan yang kurang memadai. Peluang bisnis cukup bagus jika ditangani oleh pembisnis yang professional seperti perubahan dalam kondisi persaingan, perubahan dalam peraturan perundanganundangan yang membuka berbagai kesempatan baru dalam kegiatan berusaha. Hubungan pembeli yang akrab dan hubungan pemasok bahan baku yang harmonis. Ancaman atau lebih ke hambatan adalah masuknya pesaing baru dipasar yang sudah dilayani oleh satuan bisnis , pertumbuhan pasar yang lamban.Meningkatnya posisi tawar pembeli dan atau posisi tawar pemasok bahan mentahatu bahan baku, perkembangan dan perubahan teknologi yang belum dikuasai.Karena itu diperlukan orang dan lingkungan yang kreatif unruk dapat mengembangkan ide-ide baru, hubungan dan komunikasi dengan pihk luar tanpa menghilangkn ciri khas yang dimiliki.Diperlukan sumber daya pembeayaan, manajerial, SDM, dan waktu yang memadai untuk mencapai sasaran. Di era globalisasi kita tidak dapat menerima saja tetapi harus mempunyai daya kreatif dan inovatif agar tercapai apa yang menjadi cita-cita baik individu maupun bersama. Untuk mencapai keadilan dan kemakmuran bersama.

Ekonomi kreatif dalam Okezone rektor Ninok Laksono 2011 adalah : sebuah konsep di era ekonomi baru yang mengintesifkan informasi dan kreatifitas dengan mengandalkan ide dan pengetahuan dari sumber daya manusia sebagai

http://ejurnal.binawakya.or.id/index.php/MBI 
faktor produksi yang utama. Konsep ini biasanya didukung dengan keberadaan industry kreatif yang menjadi pengejewantahanya. Sinegritas antara pemerintah, pelaku usaha dan akadenisi diharapkan dapat mempercepat ekonomi budaya di Indonesia yang pada gilirannya menumbuhkan menciptakan ketahanan ekonomi nasional Hambatannya yaitu Akses bahan baku, pemanfaatan teknologi itu sendiri, persoalan permodalan bagi pelaku usaha, perlindungan terhadap hasil cipta itu sendiri, dan ruang public yang masih kurang, Peran serta Pemerintah.

Menurut Boediono hambatan- hambatan tersebut karena kurangnya kuantitas dan kualitas SDM kreatif. Kurangnya perlindungan hak cipta. Infrastruktur teknologi informasi yang belum lompetitif. Pembeayaan belum lancar. Iklim usaha yang belum mendukung tumbuhnya pelaku usaha relatif baru. Kurang apresiasi terhadap karya dan insan kreatif. Akses pasar yang belum menggembirakan dan belum ada sinkronisasi antara kebijakan pusat dan daerah.

Ancaman-ancaman di dunia bisnis yang dapat menjadi hambatan dalam pengembangan ekonomi, seperti ancaman yang timbul karena adanya rivalitas antar pesaing, walaupun di bidang industri tekstil masih renda., Masuknya perusahaan baru ke dalam industri yang ada dengan daya tarik pasar berbeda untuk masing masing segmen pasar. Adanya produk pengganti bersifat membatasi baik harga produk maupun keuntungan yang diperoleh. Meningkatnya kemampuan bargaining dari pembeli berpengaruh terhadap harga jual sehingga pembeli mencari penjual yang menawarkan harga lebih rendah. Dan pindah dengan mudah ke penjual lain. Meningkatnya kemampuan bargaining dari supplier hal ini berpengaruh terhadap biaya produksi dari produsen. (Gunawan A, ; 2010 :141) Dengan menyadari hambatan-hambatan karena intu disampimg masyarakat memiliki kreatifitas juga harus memiliki tingkat inovasi tinggi. Inovasi adalah suatu proses untuk mengubah kesempatan menjadi ide yang dapat dipasarkan, Inovasi lebihdari sekedar ide yang baik. Suatu gagasan murni memegang peranan penting dan pikiran http://ejurnal.binawakya.or.id/index.php/MBI yang kreatif mengembangkannya menjadi gagasan berharga Hal yang lebih penting adanya penyempurnaan dari hasil pemikiran, riset dan pengalaman.Wirausahawan yang prospektif harus mempunyai keberanian untuk memberikan sebuah ide melalui tahapan pengembangan. Jadi inovasi adalah sutu kombinasi visi untuk menciptakan sutu gagasan yang baik dan keteguhan serta dedikasi untuk mempertahankan konsep melalui implementsi.( Mas'ud \& Mahmud ; 2005 :8)

Seorang wirausahawan harus dapat memadukan pikiran kreatif dan imajinatif dengan kemampuan proses yang logis dan sistematis dan berani menanggung risiko untuk memiliki pasar, karena tidak akan mudah untuk mencapainya. Karena itu daya kreatif tinggi di harapkan dapat memberikan jalan untuk terobosan-terobosan pasar yang dituju sehingga akan dapat meningkatan pendapatan untuk penguatan ekonomi keluarga bagi para perajin di Dusun Sade .Dari hal tersebut diatas perlunya diketahui faktor-faktor yang dominan dan faktor pendukung sebagai hambatan dalam pengembangan ekonomi kreatif agar bisnis utama bisa berkembang tanpa menghilangkan keunikannya karena merupakan kekuatan yang dimiliki oleh Dusun Sade. Hambatan-hambatan yang ada dapat di analisis dengan manajemen kulitas melalui pendekatan manajemen pemasaran yaitu dengan marketimg $\operatorname{mix}$

Secara manajemen kualitas sangat dibutuhkan kualitas produkagar hasilnya bagus. Dan ada standar yang harus dipenuhi untuk menjaga kualitasnya. Untuk pengembangan kreatif dibutuhkan inovasi dalam strategi produk adalah memproduksi produk limi yaitu produk kain tenun yang dijual yang menggunakan ATBM dengan injak untuk meningkatkan pendapatan sebagai dukungan dalam penguatan ekonomi keluarga, Jika mengandalkan penjualan kain tenun songket saja tidak akan dapat efektif dan efisien karena untuk menghasilkan kain tenun songket butuh waktu pengerjaan dan risikonya juga kesehatan jika dipaksakan, karena waktu bekerja penenun adalah sekitar $5 \mathrm{jam} /$ hari. Peran ibu-ibu di desa ini sangat signifikan untuk

Vol.14 No.4 Nopember 2019

\section{Open Journal Systems}


membantu pendapatan keluarga karena pekerjaan sampingan mereka adalah menenun dan ada yang berdagang hasil kerajinan tenun ikat tradisional dan accesoris tradisional. Karena itu perlunya lebih memberdayakan masyarakat dalam membantu perkembangan perekonomian melalui ibu-ibu rumah tangga dalam penguatan ekonomi keluarga.Karena itu perlunya manajemen kualitas yang berkaitan dengan manajemen pemasaran yaitu bauran pemasaran. Manajemen kualitas adalah semua aktivitas dari fungsi manajemen secara keseluruhan yang menentukan kebijakan kualitas tujuan dan tanggung jawab serta mengimplementasikannya melalui alat-lat manajemen kualitas ,penjaminan kualitas, dan peningkatan kualitas Seluruh aktivtas tersebut ditujukan bagi pencapaian totalitas karakteristik produk dan proses untuk memenuhi kebutuhan dan harapan pelanggan (Dikutip dari Gaspesrsz1997, oleh Dorothea,2003)Artinya manajemen harus dilaksanakan dalam organisasi oleh semua anggota organisasi dan menjadi pembahasan dalam pilan manajemen lain seperti manajemen operasional, manajemen SDM , manajemen keuangan,bahkan akuntansi dan manajemen pemasaran. Dan semua kegitan seluruh manajemen berperan aktif. Keterbatasan peneliti permasalahan yang dibahas hanya di bidang manajemen pemasaran.

Manajemen pemasaran adalah proses perencanaan dan pelaksanaan pemikiran ,penetapan harga, promosi, serta penyaluran gagasan, barang dan jasa untuk, rmciptakan pertukaran yang memuaskan tujuan individu, dan organisasi ( Kotler \& Keller,2009), yang berarti bahwa manajemen pemasaran adalah proses yang melibatkan analisa perencanaan, pelaksanaan dan pengendalian yang mencakup barang dan jasa dan gagasan yang tergantung pada pertukaran dengan tujuan menghasilkan kepuasan bagi pihak yang terkait. Pemasaran merupakan point penting disamping kegiatan kegiatan lain yang satu sama lain saling bersinergi. Memberikan dukungan agar manajemen dijalankan secara professional. Untuk itu memerlukan sebuah strategi dan taktik dalam mencapai tujuan perusahaan baik jangka

Vol.14 No.4 Nopember 2019 pendek maupun jangka panjang. Umumnya tujuan jangka pendek adalah mengoptimalkan laba sedangkan jangka panjang adalah dapat memperluas usaha dan memuaskan konsumen, Sebuah produk apakah berupa barang maupun jasa harus dibutuhkan oleh konsumen, digamari dan harga terjangkau agar dapat diperoleh tujuan perusahaan. Tujuan boleh sama akan tetapi strategi bisa berbeda Strategi pemasaran dari setiap perusahaan merupakan suatu rencana keseluruhan untuk mencapai tujuan. Penentuan strategi ini dapat dilakukan oleh manajer pemasaran dengan membuat tiga macam keputusan yaitu konsumen, kepuasan dan marketing mix.Dn strategi pemasaran ini menjadi pedoman bagi kegiatan-kegiatan personalia pemamasaran.satu sama lain saling berhubungan. Salah satu pendekatan tersebut adalah marketing mix

Marketing mix yang dimaksud adalah kebutuhan dan keinginan konsumen. Variabelvariabelnya adalah produk, Price, Place dan Promosi (Basu Swasta;2008:74) Kegiatankegiatan perlu dikombinasi dan dikoordinir agar perusahaan dapat melakukan tugas pemasarannya seekektif mungkin. Empat elemen pokok dalam bauran pemasaran yaitu :

Produk , mencakup keputusan penentuan bentuk penawaran secara fisik , merknya, pembungkus, garansi,dan service penjualan. Karena jenis produk adalah berupa kain tenun tradisional dan dari sisi merk adalah kain tenun ikat Desa Sade , tidak ada garansi. Pengembangan produk dapat dilakuka setelah menganalisis lebutuhan dan keinginan pasarnya. Sedangkan perajin belum melakukan hal tersebut karena mereka memproduksi semampu mereka tidak punya ekspektasi tinggi berapa harus dapat terjual atau tidak ada target karena hanya sebatas untuk membantu meningkatkan pendapatan ekonomi keluarga, secara konvensional bukan professional. Dan melakukan pekerjaan turun temurun, apabila kaum wanita tidak bisa menenun belum boleh menikah. Dan berprinsip bahwa perempuan menerima kodratnya sesuai dengan aturan yang ada, yaitu sebagai ibu rumah tangga. Kreatif produk yang dilakukan yaitu http://ejurnal.binawakya.or.id/index.php/MBI 
dengan mendesign baju lambung dengan memakai kain tenun bermotif, bukan dari kain warna hitam . Ini menjadi salah satu daya tarik. Harga, pada setiap produk berhak untuk ditentukan harga pokok produksi dan harga pokok penjualannya.Perlu adanya pertimbangan dalam penetapan harga tersebut antara lain biaya , keuntungan , praktek saingan.dan perubahan keinginan pasar.Kebijakan harga ini juga mengenai tentang penetapan jumlah potongan , mark-up, mark-down.dan lainnya. Dalam hal ini perajin menetapkan harga jual produknya tanpa jelas diketahui berapa harga pokok produksinya .Masih konvensional sehingga menjual dengan harga yang tinggi sedangkan di tingkat pasaran atau pengecer harganya lebih rendah dari harga barang yang ditawarkan di tingkat produsen.Hal ini akan dapat menjadi penghambat untuk pengembangan ekonomi dalam pemguatan ekonomi keluarga. Memang sebuah dilema bagi motivator dalam pengembangan ekonomi kreatif karena dari aspek ekonomi memang mereka tidak menjadikan ini sebuah masalah tetapi dalam meningkatkan pendapatan nasional menjadi suatu persoalan karena daerah ini dari sisi ekonomi sangat potensial dapat mendukung untuk kemajuan pendapatan asli daerah disamping menjadi tujuan wisata tetapi juga mampu memberikan kontribusi pendapatan secara nasional. Karena itu diperlukan penenapan harga produk yang efektif.

Place atau Distribusi, ada tiga aspek keputusan yang berkaitan yaitu aspek : sistem transportasi perusahaan, sistem penyimpanan, pemilihan saluran distribusi. Dalam hal ini perajin tidak menjual keluar produknya sehingga tidak memerlukan transportasi hanya jika membeli benang emas baru membeli di luar desa sedangkan untuk benang bahan bakunya adalah memintal sendiri dan mempergunakan bahan warna dari tumbuhan yang ada disekitarnya. Untuk penyimpanan atau gudang langsung di depan kamar yang ditutup dengan gedek (bambu) .Ini sebanarnya hambatan dari pengembangan ekonomi karena tidak ada kerjasama dengan para penyalur.
Promosi, yaitu untuk memperkenalkan sebuah produk dengan periklanan, personal selling, promosi penjualan, dan publisitas. Berdasarkan dari survey memang kurang promosi . Pengenalan terhadap produk karena Desa Sade menjadi salah satu tujuan wisata NTB. Tidak semata untuk hasil produk .Dan promosi dilakukan secara personal kepada pembeli yang datang ke lokasi. Dengan jalan merayu dan memberi layanan dan memberi contoh memakai produknya, yang terkenal dengan pakaian adat sasak. Dan wisatawan dan para wisatawan bisa mencoba menenun.

Dari keseluruhan variabel-variabel tersebut dapat dipergunakan sebagai dasar untuk mengambil strategi dalam usaha mendapatkan posisi yang kuat di pasar Dan perusahan dapat mempergunakan kualitas produk dan harga yaitu dapat bervariasi : kualitas produk dan harga tinggi, kualitas produk harga sedang, kualitas produk dan harga murah. Dengan demikian maka dapat di lihat bahwa hasil survey dan toeri yang ada akan dapat ditarik permasalahannya yaitu hambatan -hambatan yang dominan menjadi akar permasalahan dalam pengembangan ekonomi kreatif di Desa Sade. Partisipasi mereka sangat diperlukan. Hasil yang diharapkan yaitu pembangunan yang partisipasif menghasilkan tata pemerintahan yang lebih baik, kemakmuran yang lebih adil,, pelayanan dasar yang lebih bermanfaat bagi masyarakat banyak., akses kepasar dan jasa bisnis yang lebih merata, organisasi masyarakat yang lebih kuat dan kebebasan memilih yang lebih terbuka. Kampung Sade dipilih bukan karena masyarakat kurang mampu tetapi mempartahankan keunikan budayanya dan pesatnya perkembangan pariwisata di NTB cukup baik . Namun warga ini tetap bertahan dengan budaya dan mengantisipasi pengembangan ekonomi dengan penguatan ekonomi keluarga dengan tetap melaksanakan awig-awig yang ada, tidak berani melanggar. Sehingga ada hambatan dalam menumbuhkan ekonomi berkembang dan bersaing di era globalisasi. Mereka lebih mempertahankan budayanya, Tetapi untuk mampu memberikan partisipasi dalam pembangunan perlu dicari akar

Vol.14 No.4 Nopember 2019 
permasalahannya. Sehingga kedepan

perekonomian mereka bisa maju tanpa menghilangkan keunikan budayanya.

Penelitian ini dilakukan pada prajin yaitu ibu-ibu anggota kelompok usaha tenun ikat tradisional sasak di Dusun Sade Desa Rembitan Kecamatan Pujut Kabupaten Lombok Tengah .Penelitian ini dilaksanakan setelah peneliti melakukan pengabdian masyarakat. Untuk memberi pengetahuan, yang diharapkan dapat merubah sikap dan pola pikir masyarakat dalam partisipasi pembangunan dengan memberikan ilmu dalam memanage bisnis agar dapat memberikan efektifitas dan efisiensi penggunaan modal usaha sehingga produktivitas kerja dapat meningkat. Para ibu -ibu membantu keluarga untuk mengembangkan kreatifitas dari berbagai strategi pemasaran agar pendapatan keluarga meningkat. Karena itu perajin dan sekaligus pedagang belum mengetahui dengan jelas faktor-faktor apa yang menjadi penghambat dalam menegembangkan perekonomian agar bisa tercapai tujuannya. Akhirnya peneliti ingin membantu para perajin untuk mencari akar faktor-faktor penyebab rendahnya tingkat penjualan pedagang. Berdasarkan dari fakta dan teori adanya hambatan dalam pengembangan ekonomi kreatif Secara teeoritis faktor penyebabnya yaitu disebabkan oleh kurang efektif dan efisiennya dari bauran pemasaran. Dan agar penelitian ini dapat memberi manfaat yang signifikan dalam penguatan ekonomi keluarga. Dengan Pengembangan ekonomi kreatif akan dapat sebagai dasar untuk dapat meningkatkan pendapatan nasional di era revolusi industri 4.0., maka peneliti tertarik untuk mengambil judul yaitu : Hambatan Pengembangan Ekonomi Kreatif Di Kabupaten Lombok Tengah ( Studi Kasus PadaPerajin Kain Tenun Tradisional Dusun Sade )

\subsection{Tujuan Penelitian}

Tujuan yang ingin dicapai dalam melakukan penelitian yaitu sebagai berikut :

Untuk mencari akar permasalahan hambatan yang dihadapi dalam pengembangan ekonomi kreatif oleh perajin kain tenun tradisional Dusun Sade di Kabupaten Lombok Tengah.

Vol.14 No.4 Nopember 2019

\section{LANDASAN TEORI \\ Pengertian Kewirausahaan}

Wirausaha adalah orang-orang yang mempunyai kemampuan melihat dan menilai kesempatan-kesempatan bisnis , mengumpulkan sumber-sumber daya yang dibutuhkan guna mengambil keuntungan daripadanya serta serta mengambil tindakan yang tepat guna memastikan sukses (Geofery GMeredith et,al,1995) dikutip oleh Panji Anoroga dkk ,2002 dan kewirausahaan adalah semangat semangat, prilaku dan kemampuan untuk memberikan tanggapan yang positif terhadap peluang memperoleh keuntungan untuk diri sendiri dan atau pelayanan yang lebih baik pada pelanggan, masyarakat ; dengan selalu berusaha mencari dan melayani langganan lebih banyak dan lebih baik, serta menciptakan dan menyediakan produk yang lebih bermanfaat dan menerapkan cara kerja yang lebih efisien melalui keberanian menanggung risiko,kreatifitas dan inovasi serta kemampuan manajemen (Sa;im Siagian,1998). Dan juga kewirausahaan dikenal sebagai suatu proses penciptaan nilai dengan menggunakan berbagai sumber daya tertentu untuk mengekspoitasi peluang. Proses ini ada beberapa tahpan khusus yaitu pengidentifikasian peluang, pengembangan ( konsep ) bisnis baru, evaluasi dan pengumpulan sumber daya yang diperlukan, implementasi /penerapan konsep, pemanfaatan serta penuaian hasil dari bisnis yang dijalankan.(Moriis,Avilla,dan Aleen 1993)

Menurut Panji Anoraga dkk,2002,Ada 5 esensi pokok kewirausahaan yaitu 1. Kemauan untuk kut berkaryadengan semangat kemandirian terutama dalam bidang ekonomi, kemauan memecahkan masalah dan membuat keputusan secara sistematis termasuk keberanian mengambil risikousaha, kemauan berpikir dan bertindak secra kreatif dan inovatif, kemauan kerja keras secara teliti , tekun dan produktif, kemauan berkarya dalam kebersamaan berlandaskan etika bisnis yang sehat.

Arti penting penting kewirausahaan yaitu Wirausaha memberikan bebarapa manfaat seperti meingkatkan produktivitas dengan metode baru. Meningkatkan pertumbuhan ekonomi dan http://ejurnal.binawakya.or.id/index.php/MBI 
menciptakan pekerjaan sehingga dapat memberikan kontribusi terhadap pertumbuhan ekonomi. Menciptakan teknologi baru menciptakan produk dan jasa baru yaitu dengan produk lini.Mendorong inovasi dengan mengembangkan metode baru Membantu organisasi bisnis yang besar, pasar kecil yang memproduksi produk yang kecil karena kurang efisien jika diproduksi sendiri , jadi perusahaan besar membeli produk tersebut.

\section{Rencana Pemasaran}

a. Ruang lingkup rencana pemasaran ( marketing plan)

Sebelum menyusun marketing plan maka wirausaha harus mengetahui seluk beluk atau konsep -konsep pemasaran dan segala informsi, sehingga perlu dijawa tiga pertanyaan dikutip olehBuchari Alma: Where have we been, where do we want to go, How do we get there (Hisrich Peters, 1905).

Kegiatan marketing plan adalah : analisa situasi lingkungan dan peluang pasar, mengembangkan sasaran pemasaran, menetapkan strategi pemasarandan menciptakan taktik atau tidakan pelaksanaan. Karakteristik dari marketing plan yang baik harus memenuhi kriteria yaitu : berdasarkan fakta dan asumsi yang benar tentang siapa target market, dimana lokasi, kemungkinan berapa besar daya serapnya.Bagaimana teknik promosi yang efektif. Bagaimana perubahan harga pasar. Bagaimana Saluran distribusi. Bagaimana keadaan saingan. Bagaimana SWOT dari perusahaan. Siapkamn sumber=sumber yang diperlukan seperti sumber daya manusia, keuangan,fasilitas , perawatan dan sebagainya.

b. Konsep A I D A + S

Didalam setiap kegiatan bisnis diusahakan agar wirausaha memperhatikan konsep tersebut diatas yang merupakan singkatan dari Attention, Interest, Desire, Acton, Satisfaction yang artinya bahwa pertama jail konsumen berhubungan dengn perusahaan tentu muncul lebih dulu perhatian setelah melihat display, kemusian timbul minatnya, lalu masuk ke took. Dan minta kepada pelayan untuk menngambil barang yang diingikan.ini berarti ada keinginan yang http://ejurnal.binawakya.or.id/index.php/MBI meningkat.kemudian menanyakan harga, cocok dengan harga akhirnya dibeli.Sampai dirumah produk tersebut dipakai dan akhirnya 2 kemungkinankonsumen tersebut puas atau tidak.

Tujuan dari setiap perusahaan adalah memuaskan konsumen.Jika konsumen puas akan meakukan pembelian ulang.Dan jika tidak puas akan menyebarkan infoermasi negative sehingga pemasaran produk tersebut tidak mencapai sasaran.

c. Konsep pemasaran

Ada lima konsep pemasatran (BuchariAlma,2007) yaitu :a. Konsep produksi , produsen tipe ini akan mendistribusikan ke seluruh pelosok agar mudah diperoleh konsumen. Konsep ini untuk menguasai pasarDan akan berhasil jika sedikuit persaingan dan belum memperhatikan kualitas.Yang terpenting terpenuhi kebutuhan belum diperhatikan masalah keingina. b. Konsep produk Pada saat barang langka di pasar, maka produsen memusatkan perhatian pada teknis pembuatanproduk saja, belum memperhatikan selera konsumenhanya menuruti selera produsen, dan berprinsip bahwa konsumen membeli karena mutu. c.konsep penjualan yaitu produsen membuat barang kemudian harus menjual dengan berbagai teknik promosi, kegiatan promosi yang maksimalpemahaman konsepini konsumen pasti akan membeli barang, promosi merupakan ciri khas selling concept. D. Konssep pasar, disini produsen tidak sekedar membuat barang tidak asal melancarkan promosi akan tetapi memusatkan pemuasan selera konsumen. Produsen memperhatikan needs dan wants dari konsumen.e. Konsep pemasaran Berwirausaha Sosial yaitu adanya tingkat orientasi pda rasa tanggung jawab social dan kemanusiaan. Tuntutan dari konsumen dan pemerintah produsen harus memproduksi barang yang baik dan tidak merusk kesehatn masyarakat dan lingkungan. Tidak mmentingkan keuntungan semata. Karena itu konsep pemasaran di era globalisasi yang cocok adalah konsep marketing yang berwawasan social berusaha memenuhikebutuhan, keinginan dan minat konsumen sehingga dapat memenuhi kepuasan

Vol.14 No.4 Nopember 2019 
konsumen secara efektif dan efisien dan membuat kehidupan masyarakat menjadi lebih baik.

d. Strategi Pemasaran

Menurut Philip Kotler,and Amstrong,1999, manajemen pemasaran ialah kegiatan menganalisa, merencanakan,mengimplementasi, dan mengawasi segala kegiatan (program), guna memperoleh tingkat pertukaran yang menguntungkan dengan pembeli sasaran dalam rangka mencpai tujuan organisasi. Dan menurut Ben M.Enis,1974 ialah proses untuk meningkatkan efisiensi dan efektifitas fari kegiatan pemasaran yang dilakukan oleh individu atau oleh perusahaan.

Strategi pemasaran adalah pola keputusan dalam perusahaan yang menentukan sasaran,maksud atau tujuan yang menghasilkan kebijaksanaan utama dan merencanakan untuk penciptaan tujuan serta merinci jangkauan bisnis yang akan dicapai oleh perusahaan.Dapat juga diartikan memilih dan menganalisis pasar sasaran yang merupakan suatu kelompok orang yang ingin dicapai oleh perusahaan dan menciptakan suatu bauran pemasaran yang cocok dan yang dapat memuaskan pasar sasaran tersebut.

Dalam strategi pemasaran oleh wirausaha ada variabel yang dapat dikontrol dan tidak dapat dikontrol. Ada 4 variabel yang dapat dikontrol adalah market segmentation,market budget, timing dan marketing mix.

Salah satu yang dipergunakan sebagai pendekatan dalam analisis penelitian ini adalah marketing mix. Para pengusaha yang kreatif akan selalu menciptakan kombinasi terbaik dari elemen 7 P ( Product, Price, Place, Promotion, People, Physical Evidence, Process). Da;lam penelitian ini akan dibahan hanya $4 \mathrm{P}$ yaitu Product,Price, Place, Promotion.

a. Product adalah merupakan titik sentral dari kegiatan marketing .Semua kegitan marketing lainnya digunakan untuk menunjang pemasaran produk.Satu hal yang perlu diingat ialah bagaimanapun hebatnya usaha promosi distribusi dan harga jual yang baik, jika tidak diikuti oleh produk yang bermutu dan disenangi

Vol.14 No.4 Nopember 2019 oleh konsumen maka kegiatan marketing mix ini tidak akan berhasil.

b. Price merupakan penunjang yang sangat penting dalam kebijaksanan harga, karena dapat menentukan keberhaasilan pemasaran produk. Kebijaksanaan harga oleh produsen, grosir dan retailer. Karena itu tidak semudah itu dalam menentukan harga. Harga yang murah saja ataupun harga yang tinggi tetapi yang dimaksudkan adalah harga efektif.Sehingga diperlukan bagaimana menentukan harga yang tepat, tergantung pada faktor harga pokok barang, kualitas barang, daya beli masyarakat, keadaan persaingan , konsumen yang dituju dan faktor yang lain yang berpengaruh terhadap harga.

c. Place, sebelum produsen memasarkan produknya maka sudah ada perenanaan tentang pola distribusi yang dilakukan.Perantara sangat penting karena dapat membantu produsen ke konsumen.Distributor harus dipilih dengan hati-hati karena dalam dunia bisnis banyak kemungkinan terjadi ketidakpastian atau risiko.Jadi untuk mendorong penjualn melalui saluran distribusi dilakukan dengan memberi diskon khusus yaitu bonus, pameran, periklanan.

d. Promtion, antara promosi dan produk tidak dapat dipisahkan, ini saling bersinergi untuk suksesnya pemasaran. Yang termasuk dalam hal ini adalah advertising, personal selling ,promosi penjualan , publicity, yang kesemuanya oleh perusahaan dipergunakan untuk meningkatkan penjualan.

Jadi marketing mix suatu strategi pemasaran yang menggabungkan beberapa elemen di dalam marketing mix itu sendiriyang dilakukan secara terpadu

\section{Pengembangan Ekonomi kreatif}

Ekonomi kreatif adalah sebuah konsep di era ekonomi baru yang mengintensifkan http://ejurnal.binawakya.or.id/index.php/MBI 
informasi dan krativitas dengan mengandalkan ide dan pengetahuan dari sumber daya manusia sebagai faktor produksi yang utama . Konsep ini akan didukung dengan keberadaan industry kratif yang menjadi pengejawantahannya.

Sambutan Presiden Joko Widodo ketia membuka acara Temu Kreatif Nasional Di Tanggerang Selatan, Bantenbahwa kontribusi ekonomi kretif pada perekonomian nasional semakin nyata . Nilai tambah yang dihasilkan ekonomi kreatif juga mengalami peningkatan setiap tahun.Keyakinan akan masa depan ekonomi kreatif inilah yang mendorong Presiden membentuk Badan Ekonomi Kreatif (Bekraf) yang diharapkan berfungsi menjadi akselator pertumbuhan ekonomi kreatif Indonesia. Presiden bahkan berjanji untuk memberikan dukungan penuh dalam masalah anggaran kepada Bekraf. Namun harus disadari , upaya untuk menggerakkan sector ekonomi kreatif memerlukan kebersamaan, memerlukan sinergi dari semua pihak pelaku ekonomi kreatif . Salah satunya melalui temu kratif nasinal yang melibatkan para pelaku industry dan ekonomi kreatif untuk curah pikiran, curah gagasan, berbagi pengalaman, unjuk kerja , unjuk kratifitas untuk kemajuan sector ini. Industri kreatif juga butuh sinergi dan kerjasama antara para investor dengan para investor. Sinergi ini akan mendorong karya-karya kreatif mendapatkan nilai tambah yang besar.Menghadapi tantangan yang semakin berat ke depan kita perlu memperkuat kemampuan industry kreatif untuk bersaing dengan produkproduk ekonomi kreatif impor. Keterkaitan dengan sector-sektor lain baik kebelakang, dengan pemasok maupun keterkaitan ke depan yang menyerap susektor ekonomi perlu diperkuat.Penyenglegaraan berbagai kegiatan pameran dagang , baik berskala nasional maupun internasional diharapkan mampu mendorong tumbuhnya industry lain yang terkait, seperti peningkatan investasi, pengembangan usaha kecil, pendapatan devisa Negara, dan lainnya. Dengan demikian dapat disimpulkan bahwa "Era ekonomi kreatif " harus menjadi tulang punggung ekonomi Indonesia “.(4/8 2015).

\section{Hambatan pengembangan ekonomi kreatif}

Ada 5 kendala pengembangan ekonomi kreatif yakni akses pada bahan baku, pemanfaatan teknologi itu sendiri, persoalan permodalan bagi pelaku usaha, perlindungan terhadap hak cipta industry kreatif atau biasa disebut hak cipta dan dukungan ketersediaan ruang public yang masih kurang.

Peran serta pemerintah dalam hal ikut memacu pertumbuhan perekonomian ini sangat di harapka. Sinegritas antara pemerintah, pelaku usaha dan akademisi dapat mempercepat pertumbuhan ekonomi budaya di Indonesia yang pada gilirannya menumbuhkan dan menciptakan ketahanan ekonomi nasional. jelas Rektor UMN, Jakarta.

Indonesia masih menggunakan nomenklatur ekonomi kreatif . Kementerian Pariwisata dan Ekonomi kreatif seperti yang tercantum dalam Renbstranya kendala-kendala yang dihadapi tersebut antara lain :

1. Pengembangan industry kreatif belum optimal terutama disebabkan kurangnya daya tarik industry, adanya posisi dominan usaha kreatif , model bisnis industry kretif yang belum matang serta risiko usaha yang harus dihdapi.

2. Pengembangan konten, kreasi dan teknologi kreatif belum optimal, terutama disebabkan infrastrujtur internet belum memadai, insfrastruktur gedung pertunjukan belum mememenuhi standar, mahalnya mesin produksi, mahalnya piranti lunak penghasil produk dan jasa kreatif , kurangnya riset konten dan kurangnya pengarsipan konten

3. Kurangnya perluasan dan petrasi pasar bagi produk dan jasa kreatif di dalam dan luar negeri, kurangnya konektivitas jalur distribusi nasional, terkonsentrasinya pasar luar negeri, tingginya biaya promosi, belum diterapkannya system pembayaran online,dan rendahnya monitoring terhadap royalty, lisensi, hak cipta.

4. Lemahnya institusi kreatif terutama disebabkan adanya paying hokum yang

Vol.14 No.4 Nopember 2019 
mengatur tata kelola masing-masing subsector industry kreatif, iklim usaha belum cukup kondusif.apresiasi yang rendah dan pemvajakan yang tinggi dan transaksi elektronik belum di regulasi dengan baik

5. Minimnya akses pembeayaan pelaku sector ekonomi kreatif , terutama disebabkan belum sesuainya skema pembeayaan dengan karakteristik industry kreatif yang umumnya belum bankable, high risk high return, cash flow yang fluktuatif serta asset yang bersifat intangible.

6. Pengembangan sumber daya ekonomi kreatif belum optimal baik SDA maupun SDM antara lain masalah kelangkaan bahan baku, kesenjangan antara pendidikan dan industry serta standarisasi yang belum baik.

\section{METODE PENELITIAN}

Jenis penelitian yang dipergunakan adalah riset deskriptif yaitu metode studi kasus yang berpusat pada pemecahan masalah yang ada dengan mengumpulkan data , menyusun,menjelaskan kemudian dianalisis (Surakhmad ,1994) Dan diartikan riset yang dilakukan untuk menganalisis satu atau lebih vaeiabel tanpa membuat perbandingan atau menghubungkan antara variabel yang satu dengan yang lain .( Suliyanto, 2009)

Penentuan lokasi penelitian dilakukan dengan studi kasus yaitu Di Dusun Sade Desa Rembitan Kecamatan Pujut kabupaten Lombok Tengah. Karena desa ini adalah salah satu ikon tujuan wisata Provinsi Nusa Tenggara Barat yang mempunyai keunikan budaya dan para wanita khususnya ibu-ibu rumah tangga ikut mengembangkan ekonomi dalam membantu penguatan ekonomi keluarga. Mempunyai potensi untuk meningkatkan pendapatan asli daerah dan perekonomian nasional akan tetapi masih terbatasnya kemampuan manajerial seperti teknik dalam strategi pemasaran dan mengkombinasikan variabel-variabel pemasaran marketing mix).
Teknik

pengambilan

sampel

mepergunakan Purposive sampling merupakan penetapan sampel dengan berdasarkan kriteria kriteria tertentu . yang bertujuan memberikan informasi yang maksimal. Untuk mengetahui hambatan-hambatan dalam pengembangan ekonomi kreatif Di Dusun Sade Desa Rembitan Kecamatan Pujut Kabupaten Lombok Tengah . sampel yang diambil dari populasi perajin 30 kelompok adalah sebanyak 9 responden yaitu $30 \%$ dan ditambah 1 orang jadi sebanyak 10 responden, sebagai cadangan jika adalah salah satu berhalangan untuk memberikan informasi. Kriteria sampel adalah mempunyai jenis produk yang dijual sama dan modal rata-rata Rp.25.000.000,-. Kelompok usaha berdiri minimal 5 tahun.

Alat analisis yang digunakan adalah analisis Fishbone (Ishikawa) atau juga sering disebut dengan Cause and Effect Diagram digunakan untuk menganalisis persoalan dan faktor-faktor yang menimbulkan persoalan tersebut Diagaram tersebut dapat digunakan untuk menjelaskan sebab-sebab suatu persoalan Dan sering disebut Fishbone karena menyerupai kerangka ikan (Dorothea W.A.,2003) Analisis yang digunakan adalah pendekatan $4 \mathrm{P}$ dalam manajemen pemasaran yaitu :Product /produk, Price/ harga, Place/ distribusi, Promotion/promosi Kegunaannya adalah :Untuk menyimpulkan variasi-variasi dalam proses Untuk mengidentifikasi kategori dan sub kategori sebab-sebab yang mempengaruhi suatu karakterostik kualitas tertentu Untuk memberikan petunjuk mengenai macam-macam data yang perlu dikumpulkan adalah :

Langkah-langkah yang harus dilakukan

1. Pengumpulan data

2. Menggambarkan bagan faktor penyebab

3. Identifikasi akar masalah

4. Rekomendasi dan Implementasi

\section{HASILDAN PEMBAHASAN Deskripsi Data Langkah I :}

http://ejurnal.binawakya.or.id/index.php/MBI 
Pengumpulan data dilakukan kepada 10 responden Di Dusun Sade yaitu perajin kain tenun tradisional, Dari hasil survey dapat dilihat pada tabel 1.

Tabel 1. Hasil survey hambatan pengembangan ekonomi kreatif

\begin{tabular}{|c|c|c|}
\hline No & $\begin{array}{c}\text { Butir } \\
\text { Pertanyaan }\end{array}$ & $\begin{array}{c}\text { Hasil } \\
\text { Survey }\end{array}$ \\
\hline 1. & \begin{tabular}{ll}
\multicolumn{1}{l}{ Produk } \\
a. Kualitas \\
Produk \\
b. Metode \\
ATBM dengan \\
sek-sek \\
c. Permodalan \\
d. & Market share
\end{tabular} & $\begin{array}{l}\text { Kurang efektif } \\
\text { Kurang efektif } \\
\text { Kurang efektif } \\
\text { Kurang } \\
\text { efektif }\end{array}$ \\
\hline 2 & $\begin{array}{l}\text { Harga } \\
\text { a. Penentuan } \\
\text { Harga Pokok } \\
\text { Produksi } \\
\text { b. Penetapan } \\
\text { Harga Jual } \\
\text { c. Pelatihan } \\
\text { Akuntansi }\end{array}$ & $\begin{array}{c}\text { Kurang efektif } \\
\text { Kurang efektif } \\
\text { Sangat Kurang } \\
\text { efektif }\end{array}$ \\
\hline 3. & $\begin{array}{l}\text { Saluran Distribusi } \\
\text { a. Karakteristik } \\
\text { Perantara } \\
\text { b. Karakteristik } \\
\text { Personal } \\
\text { c. Karakteristik } \\
\text { pesaing }\end{array}$ & $\begin{array}{l}\text { Kurang efektif } \\
\text { Kurang efektif } \\
\text { Kurangefektif }\end{array}$ \\
\hline 4. & $\begin{array}{l}\text { Promosi } \\
\text { a. Produsen } \\
\text { b. Pemerintah } \\
\text { c. Mitra Kerja }\end{array}$ & $\begin{array}{l}\text { Kurang efektif } \\
\text { Kurang efektif } \\
\text { Kurang efektif }\end{array}$ \\
\hline
\end{tabular}

Sumber data primer diolah

\section{Analisis Data}

\section{Langkah II :}

Menggambarkan bagan faktor - faktor penyebab dari tabel 1 dapat digambarkan pada

Gambar 1. Diagram Fish Bone Hambatan Pengembangan Ekonomi Kreatif

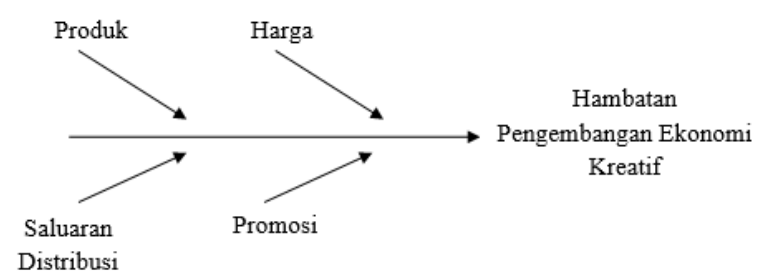

Gambar 2. Diagram Detail Fishbone Pengembangan Ekonomi Kreatif

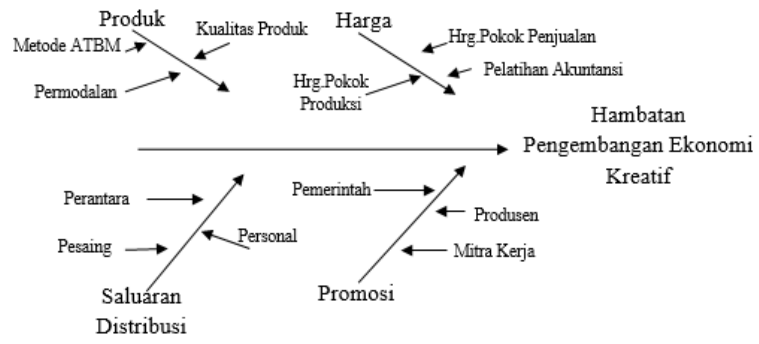

Dari hasil survey tabel 1. dapat diketahui bahwa dari 10 responden menjawab dari :

Sisi produk yaitu yang menonjol metode atau penggunaan ATBM Sek-sek kurang efektif, dapat berpengaruh terhadap kesehatan yaitu karena sikap kerja monoton, berdampak pada sakit kaki,pinggang dan punggung dan sakit kepala. Permodalan sangat kurang efektif karena masih swadaya, ini dapat berpengaruh pada tingkat laba yang akan dapat berdampak pada pendapatan keluarga dan bahkan PAD.

Sisi Harga yaitu dalam menentukan metode penetapan harga produk produksi dan penjualan san kurang efektif sehingga dapat berdampak pada perolehan tingkat pengelolaan keuangan bisnis. Perlu adanya pelatihan akuntansi yang sederhana. Agar dalam penentuannyatidak terlalu tinggi atau terlalu rendah harus jelas perhitungannya . Agar diperoleh efektifitas dan efisiensinya.

Sisi Distribusi yaitu variabel dari karakteristik perantara kurang efektif , karena peredaran barang untuk meningkatkan penjualan saluran distribusi sangat diperlukan sehingga baik dari karekteristik perantara, produsen, 
maupun pesaing, perlu dilakukan, unt,uk membantu dalam meningkatkan volume penjualan. Walaupun setiap rupiahnya keuntungannya kecil akan tetapi volume dalam partai besar laku ini akan dapat meningkatkan pendapatan.

Sisi promosi yaitu kurang efektif karena kurangnya promosi, baik media massa ,media cetak, yang dilakukan oleh produsen, pemerintah , informasi pasar dan pesaing. Sehingga penjualan rendah. Untuk itu promosi sangat penting walaupun ada beaya yang harus dikeluarkan namun dengan promosi , produk kita akan terkenal . karena banyak pembeli potensial yang belum tercover. Hal ini akan dapat meningkatkan marketshare.

Dari ke empat pendekatan manajemen pemasaran yaitu $4 \mathrm{P}$, maka dapat dianalisis bahwa produk, harga, saluran distribusi dan promosi menjadi variabel -variabel penghambat pengembangan ekonomi kreatif.

Langkah III : Mengidentifikasi akar masalah Akar masalah yang utama dari gejala adalah manajemen kualitas dengan pendekatan manajemen pemasaran yaitu produk, harga, saluran distribusi dan promosi.

Faktor produk adalah mempertahankan kualitas bahan baku dan persediaan bahan baku dan mempergunakan ATBM injak untuk kain tenun tradisional yang tidak hanya songket tetapi kain tenun untuk pakaian kerja sehari-hari, sebagai busana nasional. Untuk mengurangi risiko kesehatan dan agar volume produksi bertambah. Karena dengan ATBM dari sek-sek tidak cocok untuk membuat kain tersebut diatas kecuali untuk kain songket yang mempergunakan benang emas. Memberi tambahan modal dari pemerintah sebagai dana bergulir atau mitra kerja dalam menggalakkan investasi.

Faktor harga adalah membenahi kemampuan manejerial dalam menentukan dan menetapkan harga produksi dan harga jual . Denagn manajemen yang professional, bukan manajemen konvensioanal dengan memberikan pelatihan dan letrampilan akuntansi sederhana.

Faktor saluran distribusi adalah dengan mempertimbangakan mempergunakan perantara

\section{Vol.14 No.4 Nopember 2019}

dalam mendistribusikan produk agar dapat menembus pasar global, karena kain tenun digalakkan untuk menjadi busana nasional.

Faktor promosi yaitu kurangnya promosi baik itu media masa, media cetak, dari pemerintah maupun informasi pasar dan persaingan dan mitra kerja. Walaupun faktor ini dapat meningkatkan biaya, namun jika dikelola secara efektif dan efisien akan dapat meningkatkan volume penjualan sehingga pendapatan dapat meningkat.namun harapan yang terbesar adalah dari pemerintah untuk lebih giat mempromosikan di sector pariwisata

\section{Langkah IV :}

Rekomendasi yang diberikan :

Menjaga kualitas produk dan mendesin produk agar tetap menjadi ciri khas suku Sasak dari budaya leluhur, mempergunakan ATBM walau dengan tenun injak, karena dengan tenun sek-sek risiko kesehatan lebih tinggi dan volume produksi yang rendah.

Menemtukan harga pokok produksi dan penetapan harga jual agar lebih mengurangi risiko dalam menjaga kestabilan harga., harga lebih mudah dikendalikan dan politik harga agar berada diatas break even point. Serta memperhatikan pesaing agar tidak kalah dengan barang substitusi.

Membuka pasar untuk meningkatkan pemasaran untuk luar pulau Lombok dengan saluran distribusi yaitu mempergunakan perantara sehingga dapat menguasai market share dan berpartisipasi dalam marketplacedi era revolusi industry 4.0 serba digital.

Menggalakkan promosi dengan personal selling, pengiklanan yang diharapkan kepada pemerintah dan mitra kerja untuk membantu efektifitas pemasaran dengan tanpa menghilangkan keunikan sebagai salah satu ikon NTB di sector pariwisata.

Kepada peneliti selanjutnya dapat menjadikan penelitian ini sebagai penelitian terdahulu untuk mempengaruhi variabel variabel dari bauran pemasaran dalam mempengaruhi tingkat penjualan atau tingkat keuntungan. Dan dapat juga untuk mengetahui efektifitas dan efisiensi dari manajemen kualitas http://ejurnal.binawakya.or.id/index.php/MBI 
dengan pendekatan manajemen pemasaran. Sehingga ekoni kreatif dapat berkembang

\section{PENUTUP}

\section{Kesimpulan}

Pengembangan ekonomi kretif banyak kendalanya karena tidak mudah antara harapan dan realisasi dapat tercapai dengan efektif dan efisien. Dengan analisis Fishbone dapat ditarik kesimpulan bahwa faktor-faktor penyebab hambatan-hambatan dari sisi manajemen pemasaran yaitu $4 \mathrm{P}$ ( Product, Price, Place, Promotion ) yaitu kualitas produk sulit dijaga karena semakin menurunnya tingkat ketrampilan perajin dan risiko kesehatan yang tinggi dengan ATBM sikap kerja duduk , harga yang tidak stabil karena kadang harga di perajin lebih mahal dari harga pasar, faktor distribusi perlu dilakukan untuk menguasai market share lebih tinggi dan mempergunakan marketplace. Serta faktor promosi sangat kurang.

\section{Saran}

Disarankan kepada perajin , pemerintah , mitra kerja :

1. Untuk dapat bersinergi dalam mengimplementasikan program ekonomi kreatif yang digalakkan sebagai program nasional untuk meningkatkan pertumbuhan ekonomi lebih cepat.

2. Untuk melakukan studi banding bagi Perajin Dusun Sade seperti ke perajin yang ada di Bali untuk menambah pengetahuan yang mendapat sponsor dari mitra kerja dan pemerintah NTB khususnya dan pemerintah pusat

3. Untuk keberlanjutan ekonomi kreatif harus mempunyai kemampuan manajerial dan memasarkan barang dengan market place.untuk dapat memperluas pasar/ market share

4. Mempermudah pengurusan hak paten bagi pelaku ekonomi kratif.

\section{DAFTAR PUSTAKA}

[1] Basu Swastha, Irawan, 2008, Manajemen Pemasaran Modern, Penerbit Liberty, Yogyakarta

http://ejurnal.binawakya.or.id/index.php/MBI

Open Journal Systems
[2] Dorothea Wahyu Ariani, 2003, Manajemen Kualitas, Pendekatan Sisi Kualitatif penerbit Ghalia Indonesia, Jakarta.

[3] Faisal, Afiff, Menuju Pemasaran Global, 1994, Penerbit PT. ERESCO, Bandung

[4] Fikry Hamidy, Pendekatan Analisis FISHBONE Untuk Mengukur Kinerja Proses Bisnis Infoemasi E-Koperasi , Jurnal Teknoinfo V01.10. N0 1.2016. 103 ISSN : 16930-0010.

[5] H.Buchari Alma,2008, Kewirausahaan,untuk Mahasisw dan Umum, PenerbitAlfabeta, Bandung

[6] Gea Gita Rismahardi , Aplikasi FISHBONE ANALYSIS, dalam Mningkatkan Kualitas Pare Putih Di Aspakusa makmur, Kabupaten Boyolali, e-Jurnal Agrista, - ISSN 230-1713http/agribisnis.fp.uns.ac.id copyright@2012Program Studi Agribisnis0Fakultas Pertanian Universitas Sebelas Maret Surakarta

[7] Gunawan Adi Saputra, 2010, Mnajemen Pemasaran, Analisis Untuk Perancangan Strategi Pemasaran, Penerbit UPP STIM YKPN, Yogyakarta

[8] Geoffrey G.Meredith et al, 2002, Seri Manajemen Strategis No,1, Kewirausahaan Teori dan Praktis, Penerbit PPM, Jakarta

[9] H,Nandan LimaKrisna, Wilhelmus Hary Susilo, 2012, Manajemen pemasaran, Teori dan Aplikasi Dalam Bisnis, Penerbit Miyra Wacana Media, Jakarta

[10] https://www.maxmanroe.com?pengertianmarketing-mi.htm

[11] https://kominfo.go.id/content/detail/5277/ek onoli.kreatif-adalah-pilar-perekonomianmasadepan/0/beita

[12] https://economy.okezone.com/read/2011/11/ 18/320/531386/5-kendala-pengembanganekonomi-kreatif-di-ri

[13] https://www.umm.ac.id/en/opini/ekonomikreatif-permasalahan-tantangan-danprospeknya.htmi

[14]Kadar Rusman, 2014, Manajemen Perusahaan, Penerbit PUSTAKA SETIA, BANDUNG

Vol.14 No.4 Nopember 2019 
[15]Masiyah Kholmi, Yuningsih, 2009, Akuntansi Biaya, Penerbit Universitas Muhammadiyah Malang, Malang

[16]Mas'ud Machfoedz ,Mahmud Machfoedz, 2005, Kewirausahaan , Metode, Manajemen,dan Implementasi, Penerbit BPFE UGM, Yogyakarta

[17]Panji Anoraga, H.Djoko Sudatmoko2002,, Koperasi Kewirausahan dan Usaha Kecil, Penerbit Rineka Cipta,Jakarta

[18]Sugiyono, Metode Penelitian Bisnis , Penerbit ALFABETA, Bandung

[19]Suliyanto, 2009, Metode Riset Bisnis, Penerbit ANDI , Yogyakarta

[20] Sondang P. Siagian, 2007, Manajemen Strategik, Penerbit BUMI AKSARA, Jakarta

[21] www.google.com Ekonomi kreatif https://g.co/kgs/Qn5vgT 